\title{
Sejarah Pendidikan Islam pada Masa Khulafaur Rasyidin (11-41 H/632-661 M)
}

\author{
Erfinawati ${ }^{1}$, Zuriatin ${ }^{2,{ }^{*}}$, Rosdiana ${ }^{3}$ \\ 1,2,3.STKIP Taman Siswa Bima \\ 12erfinawati2011@gmail.com, ${ }^{2}$ atinamin57@gmail.com, ${ }^{3}$ rosediana2885@yahoo.co.id \\ ${ }^{*}$ Coresponding Author
}

\section{Artikel Info}

Tanggal Publikasi

2019-06-30

\section{Kata Kunci \\ Pendidikan Islam \\ Masa}

Khulafaur Rasidin

\begin{abstract}
Abstrak
Tujuan penulisan ini adalah untuk mengkaji lebih dalam mengenai sejarah pendidikan Islam sebelum masa Khulafaur Rasyidin dan sejarah pendidikan Islam pada masa Khulafaur Rasyidin. Penelitian ini menggunakan metode sejarah kritis melalui studi literatur. Metode yang digunakan dengan menggunakan langkah sebagai berikut. Pertama, heuristik merupakan kegiatan mencari, mengumpulkan, mengkategorikan dan meneliti sumber-sumber sejarah. Kedua, kritik sumber adalah kegiatan menguji sumber sejarah dengan menggunakan kritik ekstern dan intern Ketiga, interpretasi adalah kegiatan menafsirkan terhadap fakta yang sudah diuji dengan kritik sumber. Keempat, penyajian dengan menyampaikan sintesa yang diperoleh dalam sebuah karya sejarah. Hasil penelitian ini menunjukkan bahwa Pendidikan Islam pada masa Rasulullah dilaksanakan dalam dua periode, yaitu periode Mekah dan Madinah. Pendidikan periode Mekah dilakukan dengan tiga tahapan, yaitu tahapan sembunyi-sembunyi, tahapan secara terang-terangan dan tahapan seruan umum. Sedangkan pendidikan periode Madinah merupakan kelanjutan pendidikan di Mekah, yaitu pembentukan dan pembinaan masyarakat baru, menuju satu kesatuan sosial dan politik, pendidikan sosial politik dan kewarganegaraan serta pendidikan anak. Setelah meninggalnya Rasulullah SAW, pendidikan Islam dilanjutkan oleh Khulafaur Rasyidin. Pendidikan Islam pada masa ini dibagi menjadi empat periode, yaitu: periode Khalifah Abu Bakar asSiddiq, periode Khalifah Umar bin Khatab, periode Khalifah Usman bin Affan dan periode Ali bin Abu Thalib.
\end{abstract}

\section{PENDAHULUAN}

Pendidikan Islam dimulai sejak Nabi Muhammad SAW diangkat menjadi Rasul di Makkah dan beliau sendiri sebagai gurunya. Sejarah pendidikan Islam pada masa Nabi Muhammad SAW terbagi dua periode, yaitu Makkah dan Madinah. Pada periode Makkah, Nabi Muhammad SAW lebih menitikberatkan pada pembinaan moral dan akhlak serta tauhid kepada masyarakat Arab yang bermukim di Makkah. Pada periode Madinah, Nabi Muhammad SAW. Melakukan pembinaan dibidang social dan politik. Disinilah pendidikan Islam mulai berkembang pesat. Intisari pendidikan Islam pada periode itu disandarkan pada Al-Qur'an dan Sunnah. Pendidikan Islam masa Rasul menekankan pada pemahaman dan penghafalan Al-Qur'an.

Pasca Rasulullah SAW wafat, maka tampuk pemerintahan dilanjutkan oleh Khulafaur Rasyidin, yaitu Abu Bakar as-Shiddiq, Umar bin Khattab, Usman bin Affan dan Ali bin Abi Thalib. Masa Khulafaur Rasyidin ini berlangsung selama 32 tahun. Pada masa Khulafaur Rasyidin pendidikan dan pengajaran Islam terus tumbuh dan berkembang. Nabi Muhammad SAW. wafat (632 M) tanpa meninggalkan wasiat tentang penggantinya. Sejumlah tokoh Muhajirin dan Anshar berkumpul di balai kota Bani Sa'idah, Madinah, untuk bermusyawarah tentang tokoh yang akan menjadi pemimpin. Masing- masing pihak merasa berhak menjadi pemimpin Islam. Dalam semangat persaudaraan dan musyawarah, Abu Bakar terpilih, lalu dibai'at menjadi Khalifah. Pola pendidikan pada masa Abu Bakar masih seperti pada masa Rasulullah, baik dari segi materi maupun lembaga 
pendidikannya, namun dari segi kualitas dan kuantitasnya banyak mengalami perkembangan. Kutab dan Masjid merupakan lembaga pendidikan pada saat Rasulullah ada dan dilanjutkan oleh Khalifah Abu Bakar dan mencapai puncak kemajuan yang berarti (Ramayulis, 2012:55-56).

Setelah Abu Bakar wafat kepemimpinan Islam di serahkan kepada Umar Ibn Khattab. Pada masa kekhalifahan Umar, kondisi sosial dalam keadaan stabil, usaha perluasan wilayah Islam memperoleh hasil yang gemilang. Meluasnya kekuasaan Islam, mendorong kegiatan pendidikan Islam bertambah besar. Lembaga pendidikan pada masa Khalifah Umar Ibn Khattab sama dengan masa Abu Bakar. Namun dari segi lembaga pendidikan mengalami kemajuan yang begitu pesat, sebab selama Umar memerintah negara berada dalam keadaan stabil dan aman, hal ini menyebabkan Masjid sebagai pusat pendidikan dan juga terbentuknya pusat-pusat pendidikan Islam diberbagai kota. Pada masa kekhalifahan Umar yang menjadi guru adalah beliau sendiri dan menunjuk diantara sahabat-sahabat menjadi pendidik.

Pendidikan Islam pada masa pemerintahan Abu Bakar As-Siddiq dan Umar Ibn Khattab menggalami kemajuan yang pesat, namun pada saat kepemimpinan Utsman Ibn Affan dan Ali Ibn Abi Tholib pendidikan Islam tidak berkembang dengan pesat diakibatkan oleh banyaknya kekacauankekacauan yang terjadi.

Coretan sejarah telah mencatat bagaimana proses tumbuh dan berkembangnya pendidikan Islam yang mulai ditanamkan oleh Rasulullah SAW. dan kemudian dilanjutkan oleh para Khulafaur Rasyidin. Pada masa kepemimpinan Khulafaur Rasyidin pendidikan Islam mengalami pertumbuhan dan perkembangan, disamping itu terdapat cukup banyak negara-negara tetangga yang berhasil dikuasai. Dengan meluasnya wilayah kekuasaan Islam maka akan semakin banyak orang yang menyatakan diri masuk Islam, sehingga pendidikan Islampun ikut meluas, karena setiap wilayah yang baru dikuasai sangat membutuhkan pendidikan terutama pendidikan Islam berupa pengajaran tauhid, al-Qur'an maupun hadist. Pendidikaan sangat dibutuhkan oleh orang yang baru memeluk Islam agar keimanannya tidak mudah goyah.

Tolak ukur kemajuan suatu peradaban dunia dilihat dari kemajuan pendidikan. Masa Khulafaur Rasyidin menjadi cikal bakal bagi terbentuknya pusat dari peradaban dunia yang memberikan kontribusi bagi kemajuan peradaban-peradaban dunia, sehingga penulis memandang perlu untuk melakukan penelitian dan pembahasan lebih jauh tentang Sejarah Pendidikan Islam Pada Masa Khulafaur Rasyidin $(11-41 \mathrm{H} / 632-661 \mathrm{M})$. Selain itu, kajian ini akan bermanfaat bagi penambahan referensi kajian pendidikan Islam.

\subsection{Konsep Pendidikan Islam}

Konsep pendidikan menurut Ibnu Sina bertujuan untuk mengembangkan seluruh potensi yang dimiliki seseorang ke arah yang sempurna, yaitu perkembangan fisik, intelektual dan budi pekerti. Selain itu, tujuan pendidikan harus diarahkan pada upaya mempersiapkan seseorang agar dapat hidup di masyarakat secara bersama-sama dengan melakukan pekerjaan atau keahlian yang dipilihnya sesuai dengan bakat, kesiapan, kecenderungan dan potensi yang dimilikinya. Sedangkan konsep pendidikan modern, yaitu pendidikan yang menyentuh setiap aspek kehidupan peserta didik, pendidikan merupakan proses belajar yang terus menerus, pendidikan dipengaruhi oleh kondisikondisi dan pengalaman, baik di dalam maupun di luar situasi sekolah. Pendidikan disyaratkan oleh kemampuan dan minat peserta didik, juga tepat tidaknya situasi belajar dan efektif tidaknya cara mengajar. (Rohman 2013: i)

Menurut Ahmad Arifin, pendidikan Islam bertujuan untuk membentuk kepribadian muslim berkarakter Islam yang diimplementasikan dalam perilaku sosial sebagaimana misi diutusnya Nabi Muhammad SAW (Ahmad Arifin, 1996:226). Artinya pendidikan Islam tidak hanya bertujuan kepada dunia saja, ataupun akhirat saja. Dalam pendidikan Islam harus ada simultanitas tujuan 
pendidikan Islam kepada dunia dan akhirat

Menurut pendapat Fazlur Rahman (dalam Nurudin, 2008:131), tujuan pendidikan dalam pandangan Al-qur an adalah untuk mengembangkan kemampuan inti manusia dengan cara yang sedemikian rupa sehingga seluruh ilmu pengetahuan yang diperolehnya akan menyatu dengan kepribadian kreatifnya. Sumber dan dasar pendidikan Islam dikemukakan tiga dasar utama yaitu 1). Alquran, 2). As-Sunnah, 3). Ijtihad

Berdasarkan pengertian dan tujuan pendidikan Islam yang telah dijelaskan di awal, maka fungsi pendidikan Islam adalah memelihara dan mengembangkan fitrah dan sumber daya manusia menuju terbentuknya manusia seutuhnya (insan kamil) yaitu manusia berkualitas sesuai dengan pandangan Islam.

\subsection{Pola Pendidikan Masa Khulafaur Rasyidin}

Setelah nabi Muhammad SAW. Wafat kaum anshar menghendaki agar orang yang menganti menjadi khalifah adalah dari kalangan mereka. Ali Ibnu Abi Thalib menginginkan beliaulah yang menjadi khalifah karena ia menantu dan kerabat terdekat Nabi. Namun sebahagian besar kaum muslimin menghendaki Abubakar. Maka di pilihlah beliau menjadi khalifah. Orang-orang yang awalnya ragu segera ikut memberikan ba'iah kepada Abu Bakar sekanjutnya khalifah di lanjutkan oleh Umar Bin Khattab, Usman Bin Affan dan terakhir Khalifah Ali Ibnu Abi Thalib. Para Khalifah memusatkan perhatiannya pada pendidikan Islam, Syiar Agama, dan kokohnya agama Islam. Materi yang dicontohkan oleh Nabi SAW adalah : pendidikan tauhid, pendidikan sholat (ibadah), pendidikan adab dan sopan santun dalam keluarga dan dalam bermasyarakat (kehidupan sosial), pendidikan kepribadian, dan pendidikan hankam. ( aminah 2015 :31)

Adapun tujuan penelitian ini, yaitu sebagai berikut: (1) untuk mengetahui bagaimana sejarah pendidikan Islam sebelum masa Khulafaur Rasyidin. (2) untuk mengetahuai bagaimana sejarah pendidikan Islam pada masa Khulafaur Rasyidin.

\section{METODE PENELITIAN}

Metode penelitian yang digunakan dalam penelitian ini adalah metode penelitian historis, menurut Lois Gottschalk, metode historis adalah proses menguji dan menganalisis secara kritis rekaman dan peninggalan masa lalu (Gottschalk, 1986 : 32).

Menurut Hadari nawawi dalam bukunya "Metode Penelitian Bidang Sosial" mengatakan dalam penelitian Historis, Validitas dan Reliabilitas hasil yang dicapai sangat ditentukan oleh sifat data yang ditentukan pula oleh sumber datanya). Sifat data historis berdasarkan sumber datanya dapat diperoleh melalui data sekunder, yakni data yang mengutip dari sumber lain sehingga tidak bersifat authentic (tidak asli) karena diperoleh dari tangan kedua, ketiga dan selajutnya. ( Nawawi, 1985. 79). Jadi berdasarkan sumber datanya, maka sifat data yang peneliti gunakan untuk melakukan penelitian historis ini merupakan data yang bersifat sekunder yakni dengan mencarinya pada buku-buku literature, surat kabar dan dokumen yang sesuai, mampu menunjang dan relevan dengan penelitian ini.

Langkah-langkah penelitian historis sesuai dengan metode pelaksanaan penelitian historis yang terdiri dari empat tahapan yaitu heuristic, kritik, interpretasi, historiografi. Rincian tahapan pelaksanaannya antara lain sebagai berikut :

- Heuristic

Pada tahapan ini Peneliti mencari serta mengumpulkan data-data yang diperlukan dan berhubungan dengan penelitian yang dilakukan. 
- Kritik

Setelah data terkumpul, kegiatan peneliti selanjutnya adalah melakukan kritik terhadap sumber-sumber yang telah didapat untuk menguji apakah data tersebut valid atau tidak serta layak dan menunjang kegiatan penelitian yang dilakukan, jenis kritikan yang dilakukan dengan kritik ekstern dan intern. Kritik ekstern adalah mengkritik dengan melihat apakah data yang di dapat tesebut asli atau palsu, sedangkan kritik intern adalah mengkritik yang bertujuan untuk meneliti kebenaran isi data dari sumber data yang sudah didapat.

- Interpretasi

Peneliti melakukan penefsiran terhadap data-data yang telah didapatkan dan selanjutnya berusaha untuk melakukan analisis data atau peneliti mulai melakukan pembentukan konsep dan generalisasi sejarah

- Historiografi

Langkat terakhir yang dilakukan peneliti adalah melakukan penyusunan atau penulisan dalam bentuk laporan hingga menjadi sebuah konsep sejarah yang sistematis.

\section{HASIL DAN PEMBAHASAN}

\subsection{Sejarah Pendidikan Islam Sebelum Masa Khulafaur Rasyidin.}

Pendidikan Islam terjadi sejak Nabi Muhammad SAW. diangkat menjadi Rasul di Makkah dan beliau yang menjadi gurunya. Pendidikan masa ini merupakan prototype yang terus-menerus dikembangkan oleh umat Islam untuk kepentingan pendidikan umat pada zamannya (Hanun Asrohah, 1999:12). Pendidikan masa Rasulullah SAW terbagi menjadi dua periode antara lain sebagai berikut:

Pertama Pendidikan Islam Periode Mekkah. Pendidikan Islam pada masa Rasulullah SAW di Mekkah dilakukan dalam tiga tahapan sebagai berikut: a). Tahapan Sembunyi-sembunyi. mulanya beliau melakukannya penyiaran Islam secara diam-diam di lingkungan sendiri dan di kalangan rekanrekannya. Karena itulah orang yang pertama kali menerima dakwahnya adalah keluarga dan sahabat dekatnya. (Ramayulis, 2011:18). b). Tahapan Terang-terangan. Setelah tiga tahun dakwah Islam disampaikan secara sembunyi, turunlah perintah Allah SWT. agar Nabi melaksanakan dakwah secara terang-terangan. Perintah ini didasarkan pada Q.S. Al-Hijr ayat 94 yang artinya: "Maka sampaikanlah olehmu secara terang-terangan segala apa yang diperintahkan (kepadamu) dan berpalinglah dari orang musyrik." kemudian dilanjutkan dengan firman Allah dalam Q.S. Asy-Syuarae ayat 214 yang artinya: "Dan peringatkanlah kepada sanak family dan keluargamu terdekat. "Perintah dakwah secara terangterangan ini seiring dengan semakin bertambahnya jumlah sahabat Rasulullah dan untuk meningkatkan seruan dakwah (Abdul Kodir, 2015:41). c). Tahapan Seruan Umum. Rasulullah SAW. mengubah strategi dakwah dengan seruan umum, umat manusia secara keseluruhan. Hal ini dilakukan pada musim-musim haji ketika banyak kaum diluar Mekkah berdatangan untuk melaksanakan haji. Pada tahap ini, berkat semangat yang tinggi dari para sahabat dalam mendakwahkan ajaran Islam, seluruh penduduk Yatsrib masuk Islam, kecuali orang-orang Yahudi.

Lembaga pendidikan Islam masa Rasulullah SAW di Mekkah sebagai berikut: a). Rumah alArqam Ibn Abi Arqam b). Kuttab (Maktab) c). Manazil Ulamae (Rumah Kediaman Para Ulama) d). Masjid dan Jamiee. Adapun metode pendidikan Islam masa Rasulullah SAW di Mekkah sebagai berikut: a) Metode ceramah b) Dialog, misalnya dialog antara Rasulullah SAW. dan Mu'az ibn Jabal ketika Mu'az akan diutus sebagai kadi ke negeri Yaman, dialog antara Rasulullah SAW. dan para sahabat untuk mengatur strategi perang. c) Diskusi atau tanya jawab, yaitu sahabat bertanya kepada Rasulullah tentang suatu hukum, kemudia Rasulullah SAW. menjawabnya. d) Metode 
perumpamaan, misalnya perumpamaan yang di ucapkan oleh Rasulullah SAW. bahwa orang mukmin itu laksana satu tubuh, apabila sakit salah satu anggota tubuh, anggota tubuh yang lainnya turut merasakannya. e) Metode kisah, misalnya kisah beliau SAW. dalam isra dan mi'raj. f) Metode pembiasaan, membiasakan kaum Muslim shalat berjamaah dan ibadah-ibadah lainnya yang dianjurkan dalam Al-Qur'an dan hadis. g) Metode hafalan, misalnya para sahabat dianjurkan untuk menjaga Al-Qur'an dengan menghafalnya (Abdul Kodir, 2015:43).

Kurikulum pendidikan Islam pada periode Rasulullah SAW di Mekkah adalah Al-Qur'an, yang Allah SWT. wahyukan sesuai dengan kondisi dan situasi, kejadian dan peristiwa yang dialami umat Islam pada saat itu. Oleh sebab itu, dalam praktiknya kurikulum tersebut tidak hanya logis dan rasional, tetapi juga secara fitrah dan pragmatis. Pada fase Mekkah, materi pendidikan difokuskan pada hal-hal berikut, diantaranya: pertama, materi yang diajarkan hanya berkisar pada ayat-ayat Makiyyah sejumlah 93 surat pendek dan petunjuk Rasulullah SAW. yang dikenal dengan sunnah dan Hadis. Kedua, materi pengajarannya menitikberatkan pada keimanan, ibadah dan akhlak.

Kedua Pendidikan Islam Masa Rasulullah SAW di Madinah. Menurut Hanun Asrohah (1999:15), selama di Mekkah, Rasulullah SAW. dan para sahabat selalu mendapatkan tantangan dari kaum Quraisy yang selalu mengganggu dakwah Islam. Rasulullah SAW. akhirnya hijrah ke Madinah (Yatsrib). Kedatangan Rasulullah SAW. bersama kaum Muslim Mekkah (Muhajirin) disambut oleh penduduk Madinah (Anshar) dengan gembira dan penuh dengan rasa persaudaraan karena telah banyak penduduk Madinah yang memeluk agama Islam. Islam mendapat lingkungan baru yang memungkinkan Rasulullah SAW untuk meneruskan dakwah menyampaikan ajaran Islam (Zuhairini dkk, 1994:32). Hijrah dari Mekkah ke Madinah bukan hanya sekedar berpindah dan menghindarkan diri dari tekanan dan ancaman kaum Quraisy, tetapi juga sebagai taktik dan strategi untuk mengatur dan menyusun kekuatan dalam menghadapi tantangan-tantangan lebih lanjut, sehingga akhirnya nanti terbentuklah masyarakat baru yang di dalamnya bersinar kembali mutiara tauhid warisan Nabi Ibrahim a.s. yang akan disempurnahkan oleh Nabi Muhammad SAW. melalui wahyu Allah SWT.

Lembaga Pendidikan, Metode, dan Materi Pendidikan Islam masa Rasulullah di Madinah masih sama seperti yang di terapkan di Mekkah. Adapun lembanga pendidikan di Madinah adalah Kuttab, Masjid, dan Suffah. Metode pendidikan Islam masa Rasulullah SAW. di Madinah, antara lain: pertama, dalam bidang keimanan, yaitu melalui tanya jawab dengan penghayatan yang mendalam dan di dukung oleh bukti-bukti yang rasional dan ilmiah. Kedua, materi ibadah yaitu disampaikan dengan metode demonstrasi dan peneladanan sehingga mudah didikuti masyarakat. Ketiga, bidang akhlak yaitu Nabi SAW. menitikberatkan pada metode peneladanan. Nabi SAW. tampil dalam kehidupan sebagai orang yang memiliki kemuliaan dan keagungan baik dalam ucapan maupun perbuatan (Armai Arief, 2005:135-136).

Materi pendidikan Islam sewaktu Nabi Muhammad SAW di Madinah adalah sebagai berikut: 1) Memperdalam dan memperluas materi yang pernah diajarkan di Mekkah seperti : a) Hafalan dan penulisan dan Pengajaran Al-Qur'an masih berlangsung terus sampai dengan Rasulullah SAW. bersama para sahabatnya hijrah ke Madinah. b) Pemantapan ketauhidan umat Rasulullah SAW dalam bidang agama melakukan pembebasan dan sikap-sikap kemusyrikan, dengan pemahaman spiritualitas ajaran Islam. c) Tulisan dan baca Al-Qur'an ketika Islam datang, pendidikan baca-tulis digalakkan dan dikembangkan. d) Sastra Arab. 2) Pembentukan dan pembinaan masyarakat baru, menuju satu kesatuan sosial dan politik Nabi Muhammad SAW mulai meletakkan dasar-dasar terbentuknya masyarakat yang bersatu padu secara intern (ke dalam), dan ke luar diakui dan disegani oleh masyarakat lainnya (sebagai satu kesatuan politik). 3) Pendidikan sosial politik dan kewarganegaraan. Materi pendidikan sosial dan kewarnegaraan Islam pada masa itu adalah pokokpokok pikiran yang terkandung dalam konstitusi Madinah, yang dalam prakteknya diperinci lebih lanjut dan di sempurnakan dengan ayat-ayat yang turun selama periode Madinah. Tujuan pembinaan 
adalah agar secara berangsur-angsur, pokok-pokok pikiran konstitusi Madinah diakui dan berlaku bukan hanya di Madinah saja, tetapi luas, baik dalam kehidupan bangsa Arab maupun dalam kehidupan bangsa-bangsa di seluruh dunia (Abdul Kodir, 2015:50). 4). Pendidikan anak.

\subsection{Sejarah Pendidikan Islam Pada Masa Khulafaur Rasyidin.}

\section{Sejarah Pendidikan Islam Masa Abu Bakar As-Siddiq (11-13 H/632-634M)}

Abu bakar, nama lengkapnya adalah Abdullah bin Abi Quhafa At-Tamimi. Di zaman pra Islam bernama Abdul Ka'bah, kemudian diganti oleh nabi menjadi Abdullah. Beliau termasuk salah seorang sahabat yang utama. Dijuluki Abu Bakar (orang yang paling awal) memeluk Islam. Gelar AsSiddiq diperolehnya karena beliau dengan segera membenarkan Nabi SAW. dalam berbagai peristiwa terutama Isra' dan Mi'raj (Hasan Ibrahim Hasan, 1979:205). Beliau Sering kali mendampingi Rasulullah SAW. di saat-saat penting atau jika berhalangan, Rasulullah SAW.

Abu Bakar As-Siddiq, Khalifah Islam pertama yang dilantik oleh seluruh komunitas muslim sepeninggal Nabi Muhammad SAW ketika Rasulullah SAW. hendak wafat, beliau menunjuk Abu Bakar untuk menggantikannya menjadi imam shalat, sebab shalat merupakan salah satu kegiatan agama yang terpenting (Ibn Khaldun, 2000:250). Umar bin Khattab berkata: "Abu Bakar, bukankah Nabi sudah menyuruhmu, supaya Engkaulah yang memimpin Muslimin Bersembahyang? Engkaulah penggantinya (khalifah), kami akan mengikrarkan orang yang disukai oleh Rasulullah di antara kita semua ini," Ikrar ini disebut "Ikrar Saqifa" (Muhammad Husain Haekal, 1994:582-584). Kata-kata ini sangat menyentuh hati Muslimin yang hadir. Pihak Muhajirin datang memberikan ikrar, kemudian pihak Anshar juga memberikan ikrarnya maka di angkatlah Abu Bakar As-Siddiq seabagai khalifah pertama.

Masa awal kekhalifahan Abu Bakar diguncang pemberontakan oleh orang-orang murtad, orangorang yang mengaku sebagai Nabi dan orang-orang yang enggan membayar zakat. Berdasarkan hal ini Abu Bakar memusatkan perhatiannya untuk memerangi para pemberontak yang dapat mengacaukan keamanan dan mempengaruhi orang-orang Islam yang masih lemah imannya untuk menyimpang dari ajaran Islam (Ramayulis, 2012:56).

Abu Bakar mengirim pasukan untuk menumpas para pemberontak di Yamamah. Dalam penumpasan ini banyak umat Islam yang gugur, yang terdiri dari sahabat dekat Rasulullah SAW. dan para hafiz Al-Qur'an sehingga mengurangi jumlah sahabat yang hafal Al-Qur'an (Samsul Nizar, 2009:45). Oleh karena itu, Umar Ibn Khattab menyarankan kepada khalifah Abu Bakar untuk mengumpulkan ayat- ayat Al-Qur'an, kemudian untuk merealisasikan saran tersebut, diputuskan bahwa Zaid Ibn Tsabit ditugaskan untuk mengumpulkan semua tulisan Al-Qur'an yang masih berserakan ditempatnya. Menurut Jalaludin As-Suyuti bahwa pengumpulan Al-Qur'an ini termasuk salah satu jasa besar dari Khalifah Abu Bakar (Jalaluddin As-Suyuti, 1979:67-72).

Lembaga pendidikan pada masa Abu Bakar masih seperti lembaga pendidikan pada masa Nabi Muhammad SAW, namun dari segi kuantitas maupun kualitas sudah banyak mengalami perkembangan. a) Kutab. Pada masa Abu Bakar lembaga pendidikan Kutab mencapai tingkat kemajuan yang berarti. Kemajuan lembaga Kutab ini terjadi ketika masyarakat muslim telah menaklukkan beberapa daerah dan menjalin kontak dengan bangsa-bangsa yang telah maju. (Ramayulis, 2012:57). b) Masjid merupakan lembaga pendidikan lanjutan setelah anak tamat belajar pada kutab. Di masjid ini ada dua tingkatan, yaitu tingkat menengah dan tingkat tinggi. Yang membedakan antara kedua tingkatan tersebut adalah tingkat menengah, gurunya belum mencapai status ulama besar, sedangkan pada tingkat tinggi, para pengajarnya adalah ulama yang memiliki pengetahuan yang mendalam dan integritas kesalehan dan kealiman yang diakui oleh masyarakat (Ahmad Fuad, 1962:47).

Materi pendidikan. Materi pendidikan yang diajarkan pada Kutab adalah; (1) membaca dan 
menulis, (2) membaca Al-Qur'an dan menghafalnya, (3) Pendidikan keimanan, yaitu menanamkan bahwa satu-satunya yang wajib disembah adalah Allah, (4) Pendidikan akhlak, seperti adab masuk rumah orang, sopan santun bertetangga, bergaul dalam masyarakat, dan lain sebagainya, (5) Pendidikan ibadah seperti pelaksanaan shalat, puasa dan haji, (6) Kesehatan seperti tentang kebersihan, gerak gerik dalam shalat merupakan didikan untuk memperkuat jasmani dan rohani (Mahmud Yunus, 1989:18). Sedangkan materi pendidikan pada tingkat menengah dan tinggi adalah: (1) Al-Qur'an dan tafsirnya, (2) Hadits dan syarahnya, dan (3) Fiqih (tasyri').

\section{Sejarah Pendidikan Islam Masa Umar Ibn Khattab (13-23 H/634-644 M)}

Umar bin Khattab, nama lengkapnya adalah Umar bin Khattab bin Nufail keturunan Abdul Uzza Al-Quraisy dari suku Adi, salah satu suku yang terpandang mulia. Umar dilahirkan di Mekkah empat tahun sebelum kelahiran Nabi SAW. Umar masuk Islam pada tahun kelima setelah kenabian dan menjadi salah satu sahabat terdekat Nabi SAW serta dijadikan sebagai tempat rujukan oleh Nabi SAW mengenai hal-hal yang penting. Beliau dapat memecahkan masalah yang rumit tentang siapa yang berhak mengganti Rasulullah SAW. dalam memimpin umat setelah wafatnya Rasulullah SAW. Dengan memilih dan membai'at Abu Bakar sebagai Khalifah Rasulullah SAW. sehingga beliau mendapat penghormatan yang tinggi dan dimintai nasihatnya serta menjadi tangan kanan Khalifah yang baru itu. Sebelum meninggal dunia, Abu Bakar telah menunjuk Umar bin Khattab menjadi penerusnya (Hasan Ibrahim Hasan, 1979:210).

Abu Bakar telah merasakan persoalan yang timbul di kalangan kaum muslimin setelah Nabi SAW. wafat. Berdasarkan hal inilah Abu Bakar menunjuk penggantinya yaitu Umar Ibn Khattab. Tujuannya Abu Bakar menunjuk penggantinya agar supaya tidak terjadi perselisihan dan perpecahan di kalangan umat Islam, kebijakan Abu Bakar tersebut ternyata diterima masyarakat (Yatim, 2001:37). Pada masa Khalifah Umar Ibn Khattab, kondisi politik dalam keadaan stabil, usaha perluasan wilayah Islam memperoleh hasil yang gemilang. Wilayah Islam pada masa Umar Ibn Khattab meliputi semenanjung Arabia, Palestina, Syiria, Irak, Persia dan Mesir (Hanun Asrohah, 2001:17).

Berkaitan dengan usaha pendidikan Islam itu, Khalifah Umar mengangkat dan menunjuk guruguru untuk tiap daerah yang ditaklukkan, yang bertugas mengajarkan isi Al-Qur'an dan ajaran Islam kepada penduduk yang baru masuk Islam karena negara Islam sudah menyebar luas keluar Jazirah Arabia, maka pusat pendidikan Islam bukan di Madinah saja, tetapi tersebar juga di kota-kota besar sebagai berikut: (a) Kota Mekkah dan Madinah (Hijaz), (b) Kota Basrah dan Kufah (Iraq), (c) Kota Damsyik dan Palestina (Syria), (d) Kota Fustat (Mesir).

Panglima dan gubernur yang diangkat Umar adalah para sahabat Rasul yang telah memiliki ilmu pengetahuan agama yang luas, mereka juga adalah ulama. Seperti Abu Musa Al-Asy'ari gubernur Basrah adalah seorang ahli fiqh, ahli hadits dan ahli Qur'an. Ibnu Mas'ud dikirim oleh Umar sebagai guru, beliau adalah seorang ahli dalam tafsir dan fiqh, juga beliau meriwayatkan hadits. Muaz bin Jabal, Ubadah, dan Abu Darda' dikirim ke Damsyik untuk mengajarkan ilmu agama dan Al-Qur'an. Muaz bin Jabal mengajar di Palestina, Ubadah di Hims dan Abu Darda di Damsyik, Amru Ibnu AlAsh seorang panglima dari khalifah Umar berhasil mengalahkan Mesir. Beliau adalah seorang yang memiliki keahlian dalam hadis, terkenal sebagai pencatat hadis Nabi. Sedang di Madinah gudangnya ulama, seperti Umar sendiri seorang ahli hukum dan pemerintahan, memiliki keberanian dan kecakapan dalam melakukan ijtihad. Abdullah bin Umar adalah pengumpul hadis. Ibnu Abbas ahli tafsir Al-Qur'an dan ilmu faraid, Ibnu Mas'ud ahli Al-Qur'an dan hadis. Ali ahli hukum juga tafsir (Soekarno, dan Ahmad Supardi, 2001:55).

Masa pemerintahan khalifah Umar bin Khattab, Ali bin Abi Tholib telah menumpahkan perhatiannya pada perkembangan ilmu pengetahuan. Bersama dengan sepupunya Abdullah bin Abbas mengadakan kuliah atau pengajian sekali seminggu di masjid Jami' dalam bidang ilmu bahasa, fiqih, hadis dan termasuk filsafat khususnya logika. Begitu pula para sahabat yang lain menyampaikan 
berbagai jenis mata pelajaran di berbagai tempat (Dalimunthe, 1978:31) Dalam hal pendidikan Umar membangun tempat-tempat pendidikan (sekolah), juga menggaji guru-guru, imam, muazzin dari dana baitul mal. Khalifah Umar ibnu Khatab merupakan seorang pendidik yang melakukan penyuluhan pendidikan di kota Madinah, beliau juga menerapkan pendidikan di masjid-masjid dan pasar pasar, serta mengangkat guru-guru untuk tiap-tiap daerah yang ditaklukkan. Mereka bertugas mengajarkan isi Al-Qur'an, fiqih, dan ajaran Islam lainnya kepada penduduk yang baru masuk Islam (Nizar, 2009:47).

Masa Khalifah Umar bin Khattab, sahabat-sahabat besar yang lebih dekat kepada Rasulullah SAW., dan memiliki pengaruh besar dilarang keluar meninggalkan kota Madinah kecuali atas izin khalifah dan hanya waktu yang terbatas. Dengan demikian penyebaran ilmu para sahabat besar terpusat di Madinah sehingga kota Madinah muncul sebagai pusat studi ilmu keislaman. Meluasnya kekuasaan Islam, mendorong kegiatan pendidikan Islam bertambah besar karena mereka yang baru menganut agama Islam ingin menimba ilmu-ilmu keislaman dari para sahabat Nabi yang masih hidup yang langsung menerima pengajaran dari Rasulullah SAW., khususnya yang menyangkut Hadist Rasulullah SAW., sebagai salah satu sumber pokok ajaran Islam yang belum dibukukan hanya berdasarkan ingatan para sahabat dan sebagai alat bantu dalam menafsirkan al-Qur'an. Tidak terelakkan lagi pada masa ini terjadi mobilitas penuntut ilmu dari daerah-daerah yang jauh menuju Madinah sebagai pusat studi ilmu-ilmu agama Islam. Gairah menuntut ilmu agama Islam tersebut di belakang hari mendorong lahirnya sejumlah pembidangan disiplin ilmu keagamaan, seperti tafsir, hadist, fikih dan sebagainya. Tuntutan belajar bahasa Arab juga sudah nampak dalam pendidikan Islam pada masa Khalifah Umar. Dikuasainya wilayah baru oleh umat Islam, menyebabkan munculnya keinginan untuk belajar bahasa Arab sebagai bahasa pengantar di wilayah- wilayah baru tersebut. Orang-orang yang baru masuk Islam dari daerah- daerah yang ditaklukkan, harus belajar bahasa Arab, jika mereka ingin belajar dan mendalami pengetahuan agama Islam. Oleh karena itu, masa ini sudah terdapat pengajaran bahasa Arab. Pada masa-masa Khulafaur Rasyidin sebenarnya telah ada tingkat pengajaran, hampir seperti masa sekarang, tingkat pertama ialah kuttab, tempat anak-anak belajar menulis dan membaca/menghafal al-Qur'an serta belajar pokok-pokok Agama Islam (Yunus, 1986:39).

Berdasarkan pokok-pokok pembahasan di atas dapat kita simpulkan bahwa, mata pelajaran agama Islam pada masa khalifah Umar lebih maju dan lebih luas, serta lebih lengkap. Karena masa Umar bin Khattab negara dalam keadaan stabil dan aman, menjadikan masjid sebagai pusat pendidikan, telah terbentuknya pusat-pusat pendidikan di setiap kota.

\section{Sejarah Pendidikan Islam Masa Usman Ibn Affan (23-36 H/644-656 M)}

Usman bin Affan, nama lengkapnya adalah Usman bin Affan bin Abil Ash bin Umayyah dari suku Quraisy. Beliau memeluk Islam karena ajakan Abu Bakar dan menjadi salah seorang sahabat dekat Nabi SAW. Usman ibn Affan terkenal sebagai orang yang berbudi pekerti luhur, sangat pemalu, dermawan, lemah lembut, penuh kasih sayang, pemaaf, selalu berprasangka baik, bersikap toleransi, paling baik bergaul dengan orang lain, lapang dada lagi sabar, paling kuat menjaga hubungan kekerabatan dan terlalu lemah serta tunduk kepada keluarga (Hitty, 1974:176). Beliau sangat kaya tetapi berlaku sederhana dan sebagian besar kekayaannya digunakan untuk kepentingan Islam.

Azyumardi Azra, mengatakan setidaknya sampai abad ke-15 Mekkah dan Madinah hanya sebagai pusat ibadah dan keagamaan khususnya ibadah haji, tidak menjadi pusat keilmuan. Hal ini karena pusat-pusat keilmuan Islam justru tumbuh di tempat lain, seperti Baghdad, Kordova, dan Kairo (Mesir). Pada akhirnya, pertumbuhan dan intelektualisme Islam sangat berkait dengan dukungan dari penguasa dan kekuasaan politik. Begitupun tidak bisa diberikan oleh para penguasa Mekkah dan Madinah, karena mereka yang biasa dikenal denga 'syarif' (asyraf) justru tergantung pada 
kekuasaan politik lain. Hal ini terlihat jelas pada masa-masa Mekah dan Madinah dalam kekuasaan Dinasti Usman (Azyumardi Azra, 2002:162). Karena pada masa ini lebih banyak konflik kepentingan diantara penguasa. Pemerintahan Usman ibnu Affan berlangsung dalam dua periode, periode 6 tahun pertama ditandai oleh keberhasilan dan kejayaan, periode 6 tahun kedua ditandai oleh perpecahan tergambar dalam pergolakan dan pemberontakan dalam negeri.

Usman ibn Affan diangkat menjadi khalifah menjelang usia 70 tahun. Para ahli sejarah membagi masa pemerintahan Usman ibn Affan pada dua periode. Enam tahun pertama pemerintahan yang gemilang dan enam tahun kedua pemerintahan yang kacau. Pada enam tahun pertama ditandai dengan keberhasilan menjadikan daerah-daerah Armenia, Irtifiqiya, Cyprus, Rhodes, Tabaristan, Transoxania menjadi daerah kekuasaan Islam. Abdullah ibn Abi Sahr berhasil menembus sampai ke Afrika Utara. Dari Basrah Abdullah ibn Amir berhasil menaklukkan sisa wilayah kerajaan Sasaniyah. Dari Kufah beberapa ekspedisi militer bergerak ke Utara untuk meluaskan daerah di sekitar Laut Kaspia. Pada masa pemerintahan Usman ibn Affan berhasil dibangun Angkatan Laut yang kuat. Di antara pertempuran ini pasukan Islam dipimpin oleh Abdullah ibn Abi Sarh berhasil mengalahkan tentara Romawi di Laut Tengah dekat Iskandariyah (Shaban, 1971:91).

Banyaknya negara-negara baru yang dikuasai pada masa pemerintahan Usman bin Affan, mempengaruhi perkembangan dan kemajuan pendidikan Islam. Dengan banyaknya negara-negara yang baru dikuasai maka tidak sedikit orang yang masuk agama Islam. Masyarakat yang baru memeluk Islam sangat membutuhkan pendidikan Islam sebagai penguat agama yang baru diyakini tersebut. Mereka membutuhkan pemahaman Al-qur'an yang mudah dimegerti dan mudah dijangkau oleh alam pikirannya. Peranan hadis atau sunnah Rasul sangat penting untuk membantu dan menjelaskan Al-qur'an. Lambat laun timbullah bermacam- macam cabang ilmu hadis. Tempat belajar masih di kuttab, di masjid atau rumah-rumah. Pada masa ini tidak hanya Al-qur'an yang dipelajari tetapi Ilmu Hadis dipelajari langsung dari para sahabat Rasul (Soekarno, dan Ahmad Supardi, 2001:65-67).

Pelaksanaan pendidikan Islam pada masa Khalifah Usman bin Affan, tidak jauh berbeda dengan masa-masa sebelumnya. Pendidikan pada masa ini hanya melanjutkan apa yang telah ada. Hanya sedikit perubahan yang mewarnai pelaksanaan pendidikan Islam dari apa yang telah ada. Para sahabat besar Rasulullah SAW., yang berpengaruh dan dekat dengan Rasulullah SAW., pada masa Khalifah Umar tidak diizinkan meninggalkan Madinah, maka pada masa Khalifah Usman diberikan sedikit kelonggaran untuk keluar Madinah dan menetap di daerah-daerah yang mereka sukai. Di daerah-daerah yang baru tersebut mereka mengajarkan ilmu-ilmu keislaman yang mereka miliki dan dapatkan langsung dari Rasulullah SAW.

Usaha yang kongkrit dalam bidang pendidikan Islam belum dikembangkan pada masa Khalifah Usman bin Affan. Khalifah sudah merasa puas terhadap pendidikan Islam yang telah berjalan pada masa-masa sebelumnya. Namun, yang penting untuk dicatat, suatu prestasi yang gemilang telah dicapai pada masa pemerintahan khalifah ketiga ini adalah usaha pembukuan kitab suci Al-Qur'an yang mempunyai pengaruh yang luar biasa bagi pendidikan Islam. Khalifah Usman melanjutkan usaha yang dulu dirintis oleh Khalifah Abu Bakar yaitu pengumpulan Al-Qur'an dari hafalan-hafalan para sahabat penghafal Al-Qur'an. Bundelan itu disimpan oleh Khalifah Abu Bakar, kemudian diserahkan kepada Khalifah kedua Umar bin Khattab, setelah itu dititipkan Khalifah Umar kepada puterinya Hafsah binti Umar yang juga istri Rasulullah SAW.

Enam tahun pertama kekhalifahan Usman bin Affan, pendidikan Islam mengalami perkembangan dan kemajuan yang pesat. Sedangkan pada enam tahun terakhir masa pemerintahan Khalifah Usman bin Affan pendidikan Islam tidak mengalami kemajuan yang berarti. Hal tersebut disebabkan oleh banyaknya persoalan-persoalan sosial politik yang pada akhirnya pemerintahan Khalifah Usman bin Affan mengalami kekacauan, baik di lingkungan keluarga maupun dilingkungan 
masyarakat. Masalah tersebut memicu terjadinya pemberontakan di berbagai kalangan masyarakat, akibat dari pemberontakan tersebut Khalifah Usman terbunuh.

Usman ibn Affan terbunuh di tangan pemberontak pada Shubuh hari Jum'at bulan Zulhijjah tahun 35 Hijriyah atau bertepatan pada bulan Juni tahun 656 Masehi (Amin, 1987:87). Perbuatan kezaliman kaum pemberotak bukan saja berpengaruh terhadap diri Usman, tetapi juga memberikan pengaruh yang besar terhadap kehidupan kaum muslimin berikutnya.

\section{Sejarah Pendidikan Islam Masa Ali Ibn Abi Tholib (36-41 H/656-661 M)}

Khalifah keempat khulafaur rasyidin juga sepupu dan sekaligus menantu Nabi Muhammad SAW adalah Ali ibnu Abi Thalib. Keturunan Bani Hasyim ini lahir di Mekah tahun 603 M. Beliau adalah orang yang pertama masuk Islam dari kalangan remaja. Sepeninggal Usman, sebagian kaum muslimin menginginkan Ali bin Abi Thalib naik menjadi khalifah keempat, pada mulanya Ali menolak, tapi akhirnya mau menerima setelah mendapat desakan dari sebagian kaum muslimin. Naiknya Ali menjadi khalifah tidak disetujui oleh Bani Umayyah yang merupakan keluarga terdekat khalifah Usman. Apalagi Khalifah Ali dengan segera memecat pejabat-pejabat penting yang dulu diangkat Usman. Sebagai contoh, Khalifah Ali memecat gubernur Syria Muawiyah bin Abi Sofyan sebagai gubernur Syria, namun Muawiyah tidak terima malah dia mengangkat dirinya menjadi khalifah dan menentang Ali dengan alasan menuntut bela kematian Usman kepada Ali. Di satu sisi Ali menghadapi tantangan yang lain yaitu datangnya dari Aisyah, Thalhah dan Zubeir yang menentang Ali karena Ibnu Zubeir berambisi menjadi khalifah. Ali memusatkan perhatian untuk menghadapi pasukan Aisyah, Thalhah dan Zubeir terlebih dahulu, maka terjadilah peperangan yang dikenal dengan nama Perang Jamal (perang onta), karena panglima perangnya Aisyah pada waktu itu mengendarai onta. Pada peperangan ini pasukan Ali memperoleh kemenangan, Aisyah tertawan dan dikembalikan dengan penuh kehormatan ke Makkah, sedangkan Thalhah dan Zubeir tewas terbunuh. Kemudian Ali bersiap-siap untuk menghadapi tantangan dari pasukan Muawiyah yang sudah siap-siap untuk menentang Ali di sebuah tempat yang bernama Shiffin. Dalam peperangan tersebut pasukan Ali hampir memperoleh kemenangan, namun dalam pasukan Muawiyah terdapat seorang ahli politik yang sangat lihai, beliau mengusulkan supaya pasukan Muawiyah mengangkat mushaf Al-Qur'an tinggi-tinggi ke atas dengan ujung tombak sebagai ajakan damai. Melihat hal tersebut sebagai seorang ahli strategi militer Ali mengetahui bahwa itu hanya tipu muslihat, Ali menginginkan perang dilanjutkan karena kemenangan sedikit lagi akan diperoleh, namun Ali menghadapi desakan dari sebagian pasukannya yang menginginkan perang dihentikan karena musuh mengajak berdamai. Karena Ali terus didesak, maka dengan sangat terpaksa Ali menghentikan peperangan. Maka dicapailah perundingan damai (tahkim). Dalam peristiwa tahkim tersebut pasukan Ali terkalahkan oleh kelicikan Amru bin Ash di pihak Muawiyah bin Abi Sofyan. Karena tidak setuju dengan tahkim sebagian pasukan Ali keluar dari barisan Ali dan membentuk kelompok tersendiri. Mereka inilah dalam sejarah dikenal dengan nama golongan Khawarij. Menurut golongan Khawarij, siapa saja yang terlibat dalam peristiwa tahkim adalah kafir, maka mereka berusaha untuk membunuh Ali bin Abi Thalib, Muawiyah bin Abu Sofyan dan Amru bin Ash. Karena Ali tidak pernah menggunakan pengawal pribadi, salah seorang Khawarij yang bernama Abdurrahman bin Muljam berhasil menikam khalifah keempat ini pada Shubuh dini hari.

Kekacauan dan pemberontakan yang terjadi pada masa Khalifah Ali, membuat Syalabi berkomentar: "Sebenarnya tidak pernah ada barang satu haripun, keadaaan yang stabil selama masa pemerintahan Ali. Tak ubahnya dia sebagai seorang yang menambal kain usang, jangankan menjadi baik malah bertambah sobek. Demikianlah nasib Ali”. Lebih lanjut dijelaskan oleh Soekarno dan Ahmad Supardi, bahwa saat kericuhan politik di masa Ali ini hampir dapat dipastikan bahwa kegiatan pendidikan Islam mendapat hambatan dan gangguan walaupun tidak terhenti sama sekali. Khalifah Ali pada saat itu tidak sempat lagi memikirkan masalah pendidikan, karena seluruh 
perhatiannya ditumpahkan pada masalah keamanan dan kedamaian bagi masyarakat Islam (Supardi, 1985:59).

Dengan demikian dapat disimpulkan bahwa pendidikan pada zaman Khulafaur Rasyidin belum berkembang seperti masa-masa sesudahnya. Pelaksanaannya tidak jauh berbeda dengan masa Nabi, yang menekankan pada pengajaran baca tulis dan ajaran-ajaran Islam yang bersumber pada al-Qur'an dan Sunnah Rasul. Hal ini disebabkan oleh konsentrasi umat Islam terhadap perluasan wilayah Islam dan terjadinya pergolakan politik, khususnya pada masa pemerintahan Khalifah Ali bin Abi Thalib.

Dasar pendidikan Islam yang tadinya bermotif aqidah tauhid, sejak masa itu tumbuh di atas dasar motivasi, ambisius kekuasaan, dan kekuatan. Tetapi sebagian besar masih tetap berpegang kepada prinsip- prinsip pokok dan kemurnian yang diajarkan Rasulullah SAW. Dapat diduga, bahwa kegiatan pendidikan pada saat itu mengalami hambatan dengan adanya perang saudara. Ali sendiri saat itu tidak sempat memikirkan masalah pendidikan, karena ada yang lebih penting dan mendesak untuk memberikan jaminan keamanan, ketertiban dan ketentraman dalam segala kegiatan kehidupan, yaitu mempersatukan kembali kesatuan umat, tetapi Ali tidak berhasil. Pada masa khalifah yang keempat ini kegiatan pendidikan banyak mengalami hambatan dari berbagai pihak yang berbeda-beda kepentingan.

\section{KESIMPULAN}

Berdasakan hasil penelitian di atas dapat disimpulkan bahwa: 1) Pendidikan Islam pada masa Rasulullah dilaksanakan dalam dua periode, yaitu periode Mekah dan Madinah. Pendidikan periode Mekah dilakukan dengan tiga tahapan, yaitu tahapan sembunyi-sembunyi, tahapan secara terangterangan dan tahapan seruan umum. Sedangkan pendidikan periode Madinah merupakan kelanjutan pendidikan di Mekah, yaitu pembentukan dan pembinaan masyarakat baru, menuju satu kesatuan sosial dan politik, pendidikan sosial politik dan kewarganegaraan serta pendidikan anak. Setelah meninggalnya Rasulullah SAW, pendidikan Islam dilanjutkan oleh Khulafaur Rasyidin; 2) Pendidikan Islam masa Khulafaur Rasyidin. Pendidikan Islam pada masa ini dibagi menjadi empat periode, yaitu: periode Khalifah Abu Bakar as-Siddiq, periode Khalifah Umar bin Khatab, periode Khalifah Usman bin Affan dan periode Ali bin Abu Thalib. Pendidikan Islam periode Abu Bakar sama dengan pelaksanaan pendidikan periode Rasulullah, baik dari segi materi dan lembaga pendidikannya. Pendidikan periode Umar bin Khatab mengalami kemajuan sebab pemerintahan masa ini dalam kadaan stabil dan aman, selain itu materi juga sudah dikembangkan. Pendidikan periode Usman bin Affan tidak terdapat perkembangan jika dibandingkan dengan periode Umar bin Khatab, karena timbul pergolakan dari masyarakat sebagai akibat ketidaksenangan Usman yang mengangkat kerabatnya dalam urusan pemerintahan. Sedangkan periode Ali bin Abi Thalib pendidikan tidak mengalami perkembangan karena pada masa ini terjadi pemberontakan dan peperangan.

\section{Daftar Pustaka}

Asriya Abuddin Nata.( 2009). Sejarah Pendidikan Islam. Jakarta: Kencana.

Abdul Kodir.(2015). Sejarah Pendidikan Islam: Dari Masa Rasulullah hingga Reformasi di Indonesia, Bandung: Pustaka Setia.

Ahmad Fuad, Al Ahwani. (1962). Al Falsafah Al Islamiyah. Kairo: Dar al-Qalam. Ahmad Arifin. (1996). Ilmu Pendidikan Islam; Suatu Tinjauan Teoritis dan Praktis Berdasarkan Pendekatan Interdisipliner. Jakarta: Bumi Aksara.

Armai Arief. (2005). Sejarah Pertumbuhan dan Perkembangan Lembaga Pendidikan Islam Klasik. Bandung: Penerbit Angkasa.

A. Syalabi. (1994). Sejarah dan Kebudayaan Islam I, Jakarta: Penerbit Pustaka Alhusna. 
Asrohan, Hanun. 1999. Sejarah Pendidikan Islam. Jakarta: Logos Wacana Ilmu.

Azyumardi Azra.(2002). Histografi Islam Kontemporer - Wacana Aktualitas, dan Aktor Sejarah. Jakarta: PT Gramedia Pustaka Utama.

Dalimunthe, Fakhrur Rozy. (1986). Sejarah Pendidikan Islam. Medan: Rimbow.

Hasan Ibrahim Hassan. 1979. Tarikhul-Islam, As-Siyasi Ad-Dini As-Saqafi Al- Ijtima ${ }^{\text {ee }}$. Kairo: Maktabah An-Nahdah Al-Misriyah.

Hitti, Philip K. (1974). History of The Arabs. Britanian: The Macmillan Press.

Ibn Khaldun.( 2000). Muqaddimah. Jakarta: Penerbit Pustaka Firdaus. Jalaluddin As-Suyuti. (1979). Tarikh al-Khulafa. Beirut: Darul Fikr.

Louis Gottschalk, penerjemah Nugroho Notosusanto. (1986). Mengerti sejarah. Jakarta: Universitas Indonesia Press.

Muhammad Husain Haekal. (1994). Hayat Muhammad „Sejarah Hidup Muhammad"e. (diterjemahkan: Ali Auda). Jakarta: PT Tintamas Indonesia.

Nurudin. (2008). Hubungan Media Konsep dan Aplikasi. Jakarta: PT. Raja Grafindo Persido

Ramayulis.( 2012). Sejarah Pendidikan Islam. Jakarta: Kalam Mulia.

Nina Aminah. (2015) Pola Pendidikan Islam Periode Khulafaur Rasyidin. Bandung : Jurnal Tarbiyah Vol : 1

Samsul Nizar. (2009). Sejarah Pendidikan Islam, (Menelusuri Jejak Sejarah Pendidikan Era Rasulullah Sampai Indonesia). Jakarta: Kencana Prenada Media Group.

Soekarno, dan Ahmad Supardi. (2001). Sejarah dan Filsafat Pendidikan Islam. bandung: Penerbit Angkasa.

Yunus, Mahmud. (1986). Sejarah Pendidikan Islam. Jakarta: Hirdakarya Agung. Zakiah Drajat.(1996). Ilmu Pendidikan Islam. Jakarta: Bumi Aksara. Zuhairini.(1995). Filsafat Pendidikan Islam. Jakarta: Bumi Aksara.din. (2017). Panduan Penulisan Jurnal STKIP Taman Siswa Bima. Bima: LPPM Taman Siswa Bima. 